\title{
Особенности демографического развития Тувы: вклад миграции в демографический баланс
}

\author{
Салават И. Абылкаликов \\ Башкирский государственный университет; Национальный исследовательский университет \\ «Высшая школа экономики», Российская Федерация
}

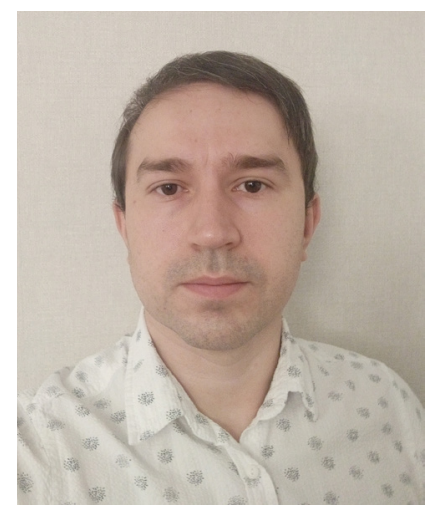

В статье выявляются особенности динамики численности населения Тувы с середины ХХ века по настоящее время за счет разных компонентов демографического баланса. В качестве основных методов исследования применены уравнение демографического баланса, который позволяет оценить соотношение между собой естественного и миграционного прироста как для всего населения, так и в городском и сельском населении по отдельности, а также анализ пожизненных миграций населения по данным информации о месте рождения и месте проживания. Данные методы для изучения демографических процессов в Туве применяются впервые. Расчеты основаны на официальной статистике - данных переписей населения (1989, 2002 и 2010 г2.), текущего учета естественного движения населения, а также выборочных обследований.

Для республики характерны недоучет выезжающих за ее пределы и переучет возвратной миграции, «виртуально» возникающей вследствие окончания срока временной регистрации ранее выехавших. Установлено, что высокие показатели естественного прироста, особенно в сельской местности, компенсируются миграционным оттоком населения из сёл в города и за пределы республики.

Отмечается, что наиболее тесные миграционные связи республики с соседними сибирскими регионами, но усиливается значение обеих столичных агломераций - Москвы и Санкт-Петербурга. При этом происходит снижение доли приехавших из других регионов России в населении Тувы и рост доли выехавших за её пределы из числа родившихся в ней. Данные выборочного обследования рабочей силы позволяют выявить усиление значения межрегиональной трудовой миграции для Тувы в последние годы. Вместе с тем объемы въезжающих и особенно выезжающих внутрироссийских трудовых мигрантов заметно ниже, чем в соседних регионах.

Накопление большой ошибки закрытия баланса из-за длительного времени, прошедшего с предыдущей переписи населения, а также изменение методики учета миграции могут привести к существенной переоценке численности населения республики по итогам следующей переписи населения.

Ключевые слова: внутренняя миграция; пожизненная миграция; трудовая миграция; демографический баланс; перепись населения; микроперепись населения; Тува; население Тувы; тувинцы

Статья подготовлена в рамках Программы фундаментальных и прикладных научных исследований «Этнокультурное многообразие российского общества и укрепление общероссийской идентичности» (2020-2022 г2.).

Для цитирования:

Абылкаликов С. И. Особенности демографического развития Тувы: вклад миграции в демографический баланс // Новые исследования Тувы. 2021. № 4. C. 131-142. DOI: https://www.doi.org/10.25178/nit.2021.4.10

\begin{abstract}
Абылкаликов Салават Иргалиевич - кандидат социологических наук, старший научный сотрудник Научной лаборатории социальных и демографических исследований факультета философии и социологии Башкирского государственного университета; старший преподаватель кафедры демографии Национального исследовательского университета «Высшая школа экономики». Адрес: 450076, Россия, г. Уфа, ул. Заки Валиди, д. 32; 109028, Россия, г. Москва, Большой Трехсвятительский пер., д. 3. Тел.: +7 (495) 772-95-90, доп. 11823. Эл. адрес: sabylkalikov@hse.ru, sabylkalikov@yandex.ru
\end{abstract}

ABYLKALIKOV, Salavat Irgalievich, Candidate of Sociology, Senior Researcher, Research Laboratory of Social and Demographic Studies, Faculty of Philosophy and Sociology, Bashkir State University; Senior Lecturer, Department of Demography, National Research University Higher School of Economics. Postal address: 32, Zaki Validi St., 450076 Ufa, Russian Federation; 3, Bolshoy Trekhsvyatitelsky Lane, 109028 Moscow, Russian Federation. Tel.: +7 (495) 772-95-90, ext. 11823. E-mails: sabylkalikov@hse.ru, sabylkalikov@yandex.ru 


\title{
Features of the Demographic Development of Tuva: Contribution of Migration to the Demographic Balance
}

\author{
Salavat I. Abylkalikov \\ Bashkir State University; National Research University Higher School of Economics, Russian Federation
}

\begin{abstract}
The article highlights the features of the population dynamics in Tuva from the mid-20th century to the present taking different components of the demographic balance into account. The main research methods the author uses are the demographic balance equation, which allows us to estimate the ratio between natural and migration growth of the entire population and of urban and rural populations separately, as well as the analysis of lifelong population migrations on the basis of information about place of birth and place of residence. These methods are applied to study demographic processes in Tuva for the first time. The calculations are based on the official statistics - data from the population censuses of 1989, 2002 and 2010, current record of natural population movement and sample surveys.

There are underestimation of those who leave the territory of the Republic of Tuva and overestimation of return migration that "virtually" arises due to the expiration of the temporary registration period of those who have left it earlier. It has been found out that high rates of natural growth, especially in rural regions, are compensated by the migration outflow of the population from villages to cities and outside the Republic.

It is noted that the Republic has the closest migration relations with neighboring Siberian regions, but the significance of both metropolitan agglomerations - Moscow and St. Petersburg - is increasing. At the same time, there is a decrease in the share of those who have come to Tuva from other regions of Russia and an increase in the share of the natives who have left it. The data of the sample survey of the labor force allow us to identify the increasing importance of interregional labor migration for Tuva in recent years. Meanwhile the number of incoming and especially outgoing domestic labor migrants is noticeably lower than in neighboring regions.

The accumulation of a large error in closing the balance due to the long time that has passed since the previous population census and a change in the migration accounting methodology may lead to a significant reevaluation of the population of the Republic if we consider the results of the next population census.
\end{abstract}

Keywords: internal migration; lifelong migration; labor migration; demographic balance; population census; micro census; Tuva; Tuvan population; Tuvans

\section{Financing}

The article was prepared within the framework of the Program of Fundamental and Applied Research "Ethnocultural Diversity of Russian Society and Consolidation of the All-Russian Identity" (2020-2022).

For citation:
Abylkalikov S. I. Osobennosti demograficheskogo razvitiia Tuvy: vklad migratsii v demograficheskii balans [Features of
the Demographic Development of Tuva: Contribution of Migration to the Demographic Balance]. New Research of Tuva,
2021, no. 4, pp. 131-142. DOI: https://www.doi.org/10.25178/nit.2021.4.10

\section{Введение}

Республика Тыва - один из наиболее своеобразных, отличающихся от остальных регионов России, в том числе и по демографическому развитию. Показатели, характеризующие естественное движение населения республики, заметно отличаются от большинства соседних регионов, включая национальные субъекты, а также в целом Сибирского федерального округа (далее - СФО) и общероссийских. Так, ожидаемая продолжительность жизни в допандемийном 2019 г. составляла 67,6 лет для обеих полов, тогда как в РФ 73,3, а в СФО - 71,1 год (в 2020 г. общая продолжительность жизни (далее - ОПЖ) в Туве для обоих полов упала на 1,3 года). Продолжительность жизни мужчин в сельской местности в республике, несмотря на стремительный рост в последние десятилетия, не превышает 60 лет и даже в относительно благополучном 2019 г. составляла всего 59,05 лет. Коэффициент младенческой смертности в Туве в постсоветское время почти вдвое превышал среднероссийский уровень, но к 2019 г. снизился до 6,6\%, тогда как для всей страны показатель был равен 4,9\%. 
При этом Тува - один из немногих регионов, в которых суммарный коэффициент рождаемости все еще выше уровня простого воспроизводства даже для городского населения $(2,45$ рождений на женщину репродуктивного возраста в 2019 г.), а в сельской местности он и вовсе достигает значения 4,32. Несмотря на относительно низкую продолжительность жизни, такой высокий уровень рождаемости компенсирует высокую смертность. Так, по общему коэффициенту естественного прироста Тува в 2019 г. со значением 10,3\% уступала только Чечне $(16,0 \%$ о) и Ингушетии $(13,4 \%$ ).

Еще одной важной составляющей демографического роста (или убыли) населения является миграция. По коэффициенту миграционного прироста среди регионов РФ Тува относится к аутсайдерам (Карачурина, Мкртчян, 2013). В начале 2010-х годов превышение числа выбывших над прибывшими на каждую тысячу постоянного населения составляло более 100 человек ежегодно, а в 2018 году -30,3\%о (в 2020 г. данный показатель вырос до -17,8\%о).

Нетто-коэффициент воспроизводства, определяющий насколько поколение дочерей замещает поколение матерей с учетом смертности, в сельской местности Тувы в 2018 г. составлял 2,658, а в городской уже опустился чуть ниже уровня простого замещения поколений - 0,970. А в целом, по республике он составлял 1,377 , то есть каждое новое поколение численно должно превышать родительское более чем на треть. Подобные показатели на уровне всей страны не наблюдаются уже на протяжении более чем шести десятилетий ${ }^{1}$.

Регион является одним из немногих в стране, где все еще не завершен демографический переход (Карачурина, Мкртчян, 2016), при котором наблюдается смена типа воспроизводства населения, переход от равновесия высокой смертности и высокой рождаемости к новому равновесию, при низких уровнях смертности и рождаемости. Тем не менее, влияние модернизационных вызовов, которое несет глобализированный мир, а также нахождение в российском институциональном пространстве неизбежно приводит к модернизационным процессам, пусть и более низкими темпами (Самба, 2020).

В условиях, когда показатели рождаемости, смертности и миграции в регионе сильно отличаются от общероссийских, составляет существенный исследовательский интерес их воздействие на формирование населения республики и динамику ее численности.

Целью данной статьи является выявление особенностей динамики численности населения Тувы с середины XX века по настоящее время за счет разных компонентов демографического баланса. В качестве основных методов исследования применены уравнение демографического баланса, который позволяет оценить соотношение между собой естественного и миграционного прироста как для всего населения, так и в городском и сельском населении по отдельности, а также анализ пожизненных миграций населения по данным информации о месте рождения и месте проживания.

Данные методы для изучения демографических процессов в Туве применяются впервые. Расчеты основаны на официальной статистике - данных переписей населения (1989, 2002 и 2010 гг.), текущего учета естественного движения населения, а также выборочных обследований - микропереписи 2015 г. (далее - МПН-2015), обследования населения по проблемам занятости (далее - ОНП3) и обследования рабочей силы (далее -OPC).

\section{Динамика численности населения и демографический баланс в 1951-2020 годы}

Со времени присоединения территории к России в 1944 г., численность населения Тувы стремительно возрастала (диаграмма 1). К концу 1980-х годов она уже удвоилась по сравнению с 1951 г. Наиболее стремительным был рост городского населения: с 56,8 тыс. чел., по данным первой послевоенной переписи населения, до 113,3 тыс. чел. к переписи 1979 г. Вслед за увеличением городского населения рос и коэффициент урбанизации - с 20-30\% в 1950-е годы до 50\% и выше - в последние десятилетия. Он увеличивался за счет более высоких темпов роста городского населения по сравнению с сельским (Харунова, Харунов, 2021). Тем не менее, доля городского населения в Туве (54\%) остается одной из самых низких во всей стране, находясь на 77 месте из 85 регионов страны.

С 1989 г. наблюдается определенный застой, а временами и стагнация динамики численности населения республики, в первую очередь за счет сокращения численности сельского населения. Если в

\footnotetext{
${ }^{1}$ Демографический ежегодник России 2019. Статистический сборник. М., Росстат, 2019 [Электронный ресурс] // Федеральная служба государственной статистики. URL: https://gks.ru/bgd/regl/B19_16/Main.htm (дата обращения: 05.09.2021).
} 


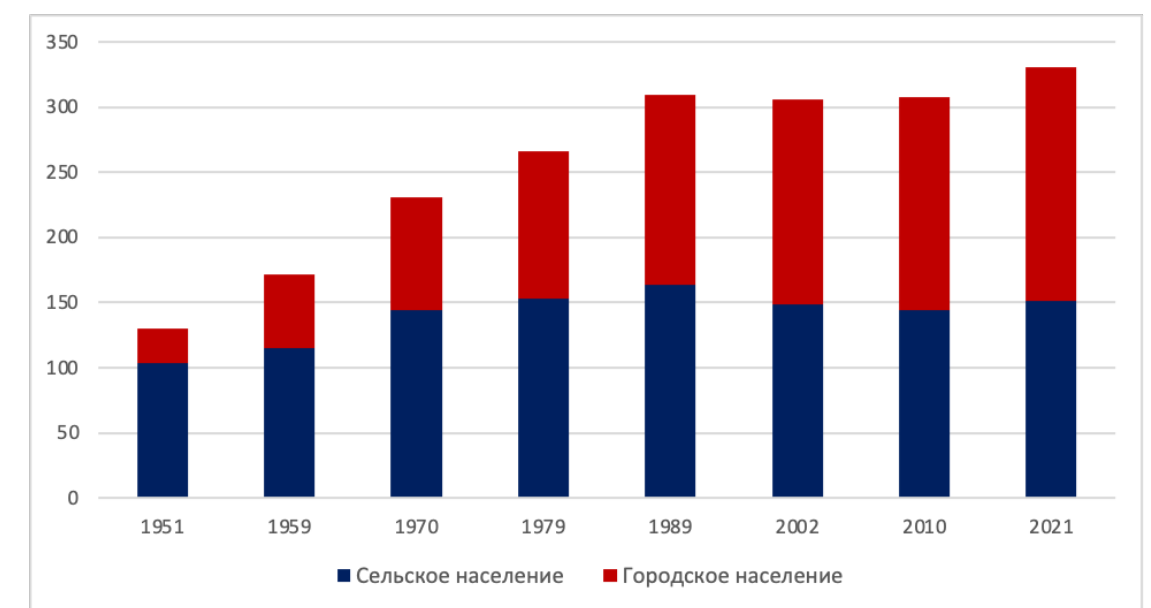

Диаграмма 1. Численность городского и сельского населения Тувы в 1951-2021 г2., тыс. чел. ${ }^{1}$

Diagram 1. The number of urban and rural inhabitants of Tuva in 1951-2021, thousand people.

Прим.: Численность населения указана на моменты проведения переписей населения, либо на 1 января соответствующего года.

1989 г. сельских жителей в регионе насчитывалось почти 163,5 тыс. чел., то по оценкам на начало 2021 г. всего 150,9 тыс. чел., доля сельского населения за это время снизилась с 53\% до 46\%. Определенные погрешности вносят и волны административно-территориальных преобразований. Так, в 1959-1996 гг. Кызыл-Мажалык являлся поселком городского типа, затем его статус вновь был сменен на сельский (Анайбан, 2011; Биче-оол, Допчут, 2015).

Стоит отметить, что в 2021 г. реальная (а не расчетная на основе данных о естественном и миграционном движении населения) численность населения Тувы вполне может быть ниже, в т. ч. даже чем по данным прошлых переписей населения. Дело в том, что с последней переписи населения прошло уже 11 лет и столь существенное время могло привести к накоплению большой ошибки закрытия баланса, то есть разницы между расчетной численностью населения на основе данных о естественном и миграционном движении населения, и численностью населения, определенной на момент проведения переписи населения, считающейся более точной (Мкртчян, 2011). Подобное наблюдалось и на прошлых переписях: в 2002 г. расчетная численность населения Тувы составляла 310 тыс. чел. (из них 151 тыс. - городское и 159 тыс. чел. - сельское ${ }^{2}$, тогда как по данным Всероссийской переписи населения (далее - ВПН) 2002 г. - 305 тыс. чел. (156 тыс. чел. городского и 149 тыс. чел. сельского населения $)^{3}$. То есть городского населения оказалось больше на 5 тыс. чел., а сельского - меньше на 10 тыс. чел. В 2010 г. история была схожей - расчетная численность по текущему учету составила 317 тыс. чел. (163 тыс. чел. городское население и 154 тыс. чел. - сельское) ${ }^{4}$, а по данным ВПН-2010 численность постоянного населения республики составило 307 тыс. чел., причем городского населения оказалось меньше на 2 тыс. чел., а сельского - на 8 тыс. чел. ${ }^{5}$

Подобная разница обычно возникает из-за недоучета миграции (Чудиновских, 2010). В случае Тувы - наибольший недоучет возникал в сельской местности. С 2011 г. российская миграционная статистика учитывает и тех мигрантов, кто зарегистрирован по месту жительства и месту пребывания на

${ }^{1}$ Составлено по данным переписей населения и текущего учета.

${ }^{2}$ Демографический ежегодник России 2002. Статистический сборник. М., Росстат, 2002 [Электронный ресурс] // Федеральная служба государственной статистики. URL: https://www.gks.ru/bgd/regl/B02_16/Main.htm (дата обращения: 05.09.2021).

${ }^{3}$ Демографический ежегодник России 2005. Статистический сборник. М., Росстат, 2005 [Электронный ресурс] // Федеральная служба государственной статистики. URL: https://www.gks.ru/bgd/regl/B05_16/Main.htm (дата обращения: 05.09.2021).

${ }^{4}$ Демографический ежегодник России 2010. Статистический сборник. М., Росстат, 2010 [Электронный ресурс] // Федеральная служба государственной статистики. URL: https:/www.gks.ru/doc_2010/demo.pdf (дата обращения: 05.09.2021).

${ }^{5}$ Демографический ежегодник России 2012. Статистический сборник. М., Росстат, 2012 [Электронный ресурс] // Федеральная служба государственной статистики. URL: https://www.gks.ru/bgd/regl/B12_16/Main.htm (дата обращения: 05.09.2021). 
срок девять месяцев и более (а не на срок от 1 года, как было ранее), что вызвало резкое увеличение числа внутренних мигрантов (Мкртчян, Карачурина, 2014). Возможно, миграция за межпереписной интервал 2011-2021 гг. будет учитываться полнее, чем это было в прежние годы.

Но вместе с тем, возникли и новые проблемы с качеством статистики - изменения в методике учета, т. е. автоматический учет мигрантов в качестве выбывших после окончания срока временной регистрации, вероятно, способствует искусственному завышению притока в сельскую и периферийную местность ранее выехавших оттуда. Прежде всего, это касается образовательной миграции молодежи, стремительный рост интенсивности которой начинается уже с 16 лет. С 2011 г. значительно увеличиваются коэффициенты миграции для возрастов в интервале 19-22 лет, что примерно соответствует окончанию обучения и, соответственно, срока их регистрации в общежитиях образовательных учреждений, но этих перемещений выпускников образовательных учреждений в реальности (а не «виртуально», на «бумаге») может и не быть (Мкртчян, 2020).

Для наиболее точной оценки миграционного прироста (убыли), а также определения его соотношения с уровнями общего и естественного приростов по межпереписным интервалам, можно воспользоваться уравнением демографического баланса. Согласно уравнению, миграционный прирост составляет разность между общим и естественным приростами. Предполагается, что естественное движение населения (т. е. процессы рождаемости и смертности) текущим учётом выявляются более полно и корректно, чем миграционное движение. Общий прирост можно вычислить непосредственно по результатам переписи в качестве разности между оценками численности населения на последующую и предыдущую переписи населения (Денисенко, Степанова, 2012).

Численность городского и сельского населения Тувы на 1951 г. приведена согласно статсборнику «Население СССР. 1987»1. Статистика естественного движения Тувы доступна начиная с 1946 г. $^{2}$ Соотношение между собой естественного (ЕП), миграционного (МП) и общего приростов (ОП) для интервалов 1951-1958 и 2011-2020 гг. является оценочным, скорее направленными на установление приблизительного соотношения между разными видами приростов (или убыли) (таблица 1). Стоит отметить, что небольшие погрешности могли происходить и из-за изменений в административнотерриториальном делении, о чем уже было упомянуто выше.

Таблица 1 Демографический баланс населения Тувы, 1951-2020 годы

Table 1. Demographic balance of the population of Tuva, 1951-2020.

\begin{tabular}{|c|c|c|c|c|c|c|c|c|c|}
\hline \multirow{2}{*}{ Годы } & \multicolumn{3}{|c|}{ Все население } & \multicolumn{3}{|c|}{ Городское население } & \multicolumn{3}{c|}{ Сельское население } \\
\cline { 2 - 10 } & ОП(У) & ЕП(У) & МП(У) & ОП(У) & ЕП(У) & МП(У) & ОП(У) & ЕП(У) & МП(У) \\
\hline $1951-1958$ & 41928 & 28655 & 13273 & 30759 & 6809 & 23950 & 11169 & 20668 & -9499 \\
\hline $1959-1969$ & 58936 & 54895 & 4041 & 30232 & 12845 & 17387 & 28704 & 41763 & -13059 \\
\hline $1970-1978$ & 35589 & 43409 & -7820 & 26274 & 12336 & 13938 & 9315 & 31073 & -21758 \\
\hline $1979-1988$ & 42676 & 55545 & -12869 & 32378 & 19314 & 13064 & 10298 & 36231 & -25933 \\
\hline $1989-2002$ & -3619 & 33656 & -37275 & 11656 & 10991 & 665 & -15275 & 22665 & -37940 \\
\hline $2003-2010$ & 2420 & 24982 & -22562 & 6103 & 10559 & -4456 & -3683 & 14423 & -18106 \\
\hline $2011-2020$ & 22438 & 42400 & -19962 & 16069 & 21220 & -5151 & 6369 & 21180 & -14811 \\
\hline
\end{tabular}

Прим.: Серой заливкой обозначена убыль населения; более темная заливка указана для убыли более 10 тыс. чел.

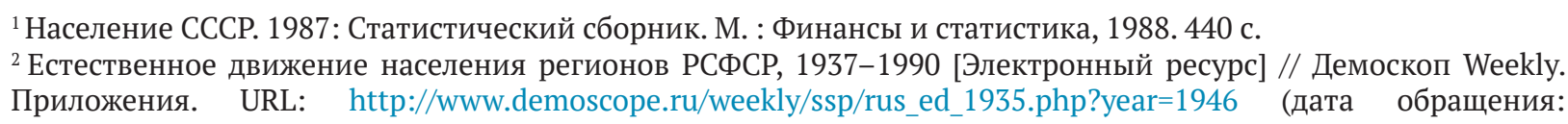
Приложения.

${ }^{3}$ Составлено автором по данным переписей населения и текущего учета. 
За наблюдаемое время (1951-2020 гг.) как в регионе в целом, так и в городской, и в сельской местностях, наблюдался естественный прирост, при этом в сельской местности естественный прирост сопровождался миграционным оттоком. Общий прирост для всего населения республики был отрицателен лишь в 1989-2002 гг., вызванный значительным превышением числа выбывших над прибывшими в сельской местности (-37,9 тыс. чел.). Согласно подсчетам по уравнению демографического баланса, суммарные «потери» населения Тувы за 1970-2020 гг. в результате миграционной убыли составляют около 100 тыс. человек.

Для городского населения в последние годы характерно сочетание естественного прироста и миграционной убыли, но с положительным общим приростом, тогда как в сельском населении миграционный отток в 1989-2010 гг. перекрывал естественный прирост. Таким образом, сельская местность является серьезным «поставщиком» мигрантов в города Тувы и, вероятно, в другие регионы России. Всего же за 1951-2020 гг. сельская местность Тувы в результате миграционной убыли потеряла около 141 тыс. чел., что соразмерно с ее современной численностью.

Вполне вероятно, что предстоящая Всероссийская перепись населения 2021 г., как и предыдущие, выявит недоучет выбытий (и, соответственно, миграционной убыли) миграционной статистикой как сельского населения, так и всей республики. Выявленный недоучет может достигнуть масштабов, настолько увеличивших оценки миграционной убыли, которые приведут к отрицательным значениям общего прироста за последний межпереписной интервал, как это произошло по данным ВПН-2002.

\section{Пожизненная миграция в республике по данным переписей населения}

Начиная с 1989 г., в программу всех отечественных переписей и микропереписей населения вновь включен важнейший миграционный вопрос - о месте рождения (ранее он задавался только в двух переписях населения - 1897 и 1926 гг.). При помощи этого вопроса можно установить, какая часть населения региона является уроженцами других территорий (субъектов России, республик бывшего СССР, стран дальнего зарубежья), а какая часть - из родившихся в Туве на моменты проведения переписей и микропереписей проживали в других регионах РФ (Abylkalikov, Sazin, 2019). В таблице 2 приведены основные параметры, характеризующие пожизненную миграцию в республике, включающие только тех мигрантов, кто родился и переселялся внутри территории России (т. е. по т. н. «внутрироссийской миграционной матрице»).

Таблица 2 Пожизненная миграция в Туве, по данным переписей 1989-2010 г2., чел. ${ }^{1}$

Table 2. Lifelong migration in Tuva according to the censuses carried out in 1989-2010, number of people.

\begin{tabular}{|c|c|c|c|}
\hline Показатели & 1989 & 2002 & 2010 \\
\hline Численность населения Тувы & 308557 & 305510 & 307930 \\
\hline Число приехавших из других регионов РФ & 49070 & 22654 & 15642 \\
\hline $\begin{array}{l}\text { Число приехавших из других республик бывшего СССР, дальнего } \\
\text { зарубежья и место рождения не указано }\end{array}$ & 7717 & 3867 & 5280 \\
\hline Численность всех уроженцев Тувы, проживающих в РФ, включая Туву & 287152 & 330911 & 340481 \\
\hline Число уроженцев Тувы, уехавших в другие регионы РФ & 35382 & 51922 & 53473 \\
\hline
\end{tabular}

По данным переписи 1989 г., доля приехавших среди всех постоянных жителей была 16,3\%, затем этот показатель многократно снизился (до 7,5\%, по данным ВПН-2002, и 5,2\%, по данным ВПН-2010). Это могло быть вызвано двумя процессами: сокращением числа неместных уроженцев в результате того, что именно они стали в первую очередь выезжать из республики, а также тем, что среди приехавших давно уже преобладали люди в старших возрастах, которые не доживали до следующих переписей (Анайбан, Губогло, Козлов, 1999). Оба процесса приводили к сокращению числа проживающих в республике этнических русских. При этом, по данным переписи 2010 г. по доле жителей-уроженцев «своих» регионов Республика Тыва (97,3\%), помимо в Дагестана (97,7\%), Чечни $(87,2 \%)$ и Башкортостана $(87,6 \%)$ является одним из лидеров в стране.

${ }^{1}$ Составлено автором по данным переписей населения 1989-2010 гг. 
Категории родившихся за рубежом (включая ближнее и дальнее) и тех, чье место рождения неизвестно, в Туве довольно небольшие - 7,7 тыс. чел. по данным переписи 1989 г., 3,9 тыс. чел. по переписи 2002 г. и 5,3 тыс., по переписи 2010 (или менее 2,5\% от населения, учтенного переписью).

Если в переписи 1989 г. доля уехавших в другие регионы РФ уроженцев Тувы составляла 12,3\% от числа родившихся в республике, то, по данным переписей 2002 и 2010 гг., она выросла до 15,7\%. При этом значительно выросли и число уроженцев республики, и численность уехавших из нее - по данным последних трех переписей их стало больше в 1,5 раза. Если к 1989 г. число уроженцев Тувы, проживающих в стране (287,1 тыс. чел), было меньше, чем численность населения Тувы (308,6 тыс. чел), то к ВПН-2010 уроженцев Тувы стало на 32,6 тыс. чел. больше (340,5 и 307,9 тыс. чел. - соответственно). Гипотетически, при сохранении доли уехавших на уровне 1989 г. (12,3\% от числа родившихся в регионе), численность республики в 2010 г. могла бы составить около 318,4 тыс. чел. вместо 307,9 тыс. чел, согласно переписи населения.

Информация о месте рождения, полученная по данным переписей и МПН-2015, позволяет определить распределение по регионам среди приехавших в Республику Тыва и уехавших из нее уроженцев ${ }^{1}$. В таблице 3 приведена подобная информация по внутрироссийской миграционной матрице. Заметные отличия по данным МПН-2015 могут быть вызваны в том числе и небольшим объемом выборки (1,5\% от населения страны).

Таблица 3. Доли приехавщих уроженцев других регионов РФ и уехавщих в другие регионы уроженцев Тувы (внутрироссийская матрица), 1989-2015 г2., в \%

Table 3. The share of people who have come to Tuva from other regions of the Russian Federation and natives of Tuva who have left for other regions (Russian domestic matrix), 1989-2015, in \%.

\begin{tabular}{|c|c|c|c|c|c|c|c|c|}
\hline \multirow{2}{*}{ Регионы } & \multicolumn{4}{|c|}{ Приехавшие } & \multicolumn{4}{|c|}{ Уехавшие } \\
\hline & 1989 & 2002 & 2010 & 2015 & 1989 & 2002 & 2010 & 2015 \\
\hline Красноярский край & 47,2 & 44,0 & 44,0 & 33,6 & 25,6 & 31,0 & 32,9 & 31,0 \\
\hline Республика Хакасия & 4,2 & 6,8 & 6,6 & 8,0 & 11,8 & 14,3 & 15,8 & 30,7 \\
\hline Новосибирская область & 2,5 & 2,6 & 2,8 & 3,6 & 3,7 & 4,0 & 5,8 & 2,6 \\
\hline Иркутская область & 3,2 & 3,7 & 4,6 & 4,4 & 5,7 & 3,8 & 5,3 & 2,3 \\
\hline Кемеровская область & 4,8 & 4,8 & 5,3 & 5,5 & 4,4 & 2,9 & 3,7 & 4,4 \\
\hline Алтайский край & 5,3 & 4,7 & 4,6 & 3,4 & 2,3 & 2,2 & 2,4 & 1,7 \\
\hline Республика Бурятия & 1,3 & 1,8 & 2,0 & 1,3 & 2,4 & 1,5 & 2,3 & 2,6 \\
\hline Забайкальский край & 1,6 & 1,7 & 2,1 & 0,9 & 1,3 & 1,1 & 0,8 & 0,6 \\
\hline Москва и МО & 0,9 & 1,3 & 1,5 & 1,4 & 4,2 & 4,4 & 4,7 & 4,2 \\
\hline $\begin{array}{l}\text { Санкт-Петербург и } \\
\text { Ленинградская область }\end{array}$ & 0,6 & 0,6 & 0,8 & 0,1 & 2,2 & 1,8 & 1,8 & 0,8 \\
\hline Остальные регионы & 28,5 & 27,9 & 27,9 & 37,9 & 36,5 & 32,9 & 25,2 & 20,8 \\
\hline
\end{tabular}

Миграционные связи Тувы наиболее тесные с соседними сибирскими регионами, особенно с Красноярским краем и Хакасией. Из «западных» регионов можно выделить только оба столичных региона - Москву с Московской областью и Санкт-Петербург с Ленинградской областью. Показатели

\footnotetext{
${ }^{1}$ Миграция. Раздел VII [Электронный ресурс] // Микроперепись населения 2015. URL: https://www.gks.ru/free doc/new_site/population/demo/micro-perepis/finish/micro-perepis.html (дата обращения: 05.09.2021).

${ }^{2}$ Составлено автором по данным переписей населения 1989-2010 гг. и МПН-2015.
} 
по столичным городам и их областям были объединены, т. к., по мнению автора данного исследования, во-первых, они являются едиными центрами притяжения внутренних мигрантов, несмотря на формальный статус разных субъектов федерации, а, во-вторых, в абсолютном выражении речь идет не об очень больших значениях.

Вместе с тем, именно со столичными регионами в последнее время усиливаются миграционные связи. Возрастает не только число уехавших туда, но тех, кто вернулся обратно, в т. ч. после завершения обучения (Ламажаа, 2014). При этом у исследователей имеются веские основания полагать, что в Москве и области (а возможно и в северной столице и Ленинградской области) существует серьезная недооценка уроженцев других регионов в населении, включая выходцев из Тувы, по данным последних двух переписей, вследствие не очень высокого качества проведения переписей в них (Мкртчян, 2011; Андреев, 2012; Пьянкова, 2014).

\section{Межрегиональная трудовая миграция в Республике Тыва}

Среди факторов, приводивших к росту числа выезжающих из республики, исследователи выделяют низкий уровень жизни (в 2010 г. уровень доходов был примерно наполовину ниже среднего по стране и на треть ниже, чем по Сибирскому федеральному округу), обеспеченность жильем (всего $65,8 \%$ от общероссийского уровня) и одни из наиболее высоких показателей безработицы. Все это вкупе приводит к нарастающему в последние кризисные годы «экономическому пессимизму» и оттоку, прежде всего, представителей нетитульных этнических групп (Кан, 2014; Балакина, Анайбан, 2016).

Исследователи отмечают, что по уровню безработицы Тува входит в число российских аутсайдеров, вместе с республиками Северного Кавказа (Ингушетией, Северной Осетией (Аланией), Дагестаном, Карачаево-Черкесией и Кабардино-Балкарией), а также Республикой Алтай (Анайбан, 2020).

Такое положение вещей может приводить не только к выезду выходцев из Тувы на постоянное место жительство, но и к активизации трудовой миграции, в качестве альтернативы отъезда на безвозвратной основе. Объемы межрегиональной трудовой миграции в республике можно оценить при помощи выборочного обследования рабочей силы (ОРС) до 2016 г. - обследования населения по проблемам занятости (ОНПЗ), реализуемого Росстатом (диаграмма 2). ${ }^{1}$

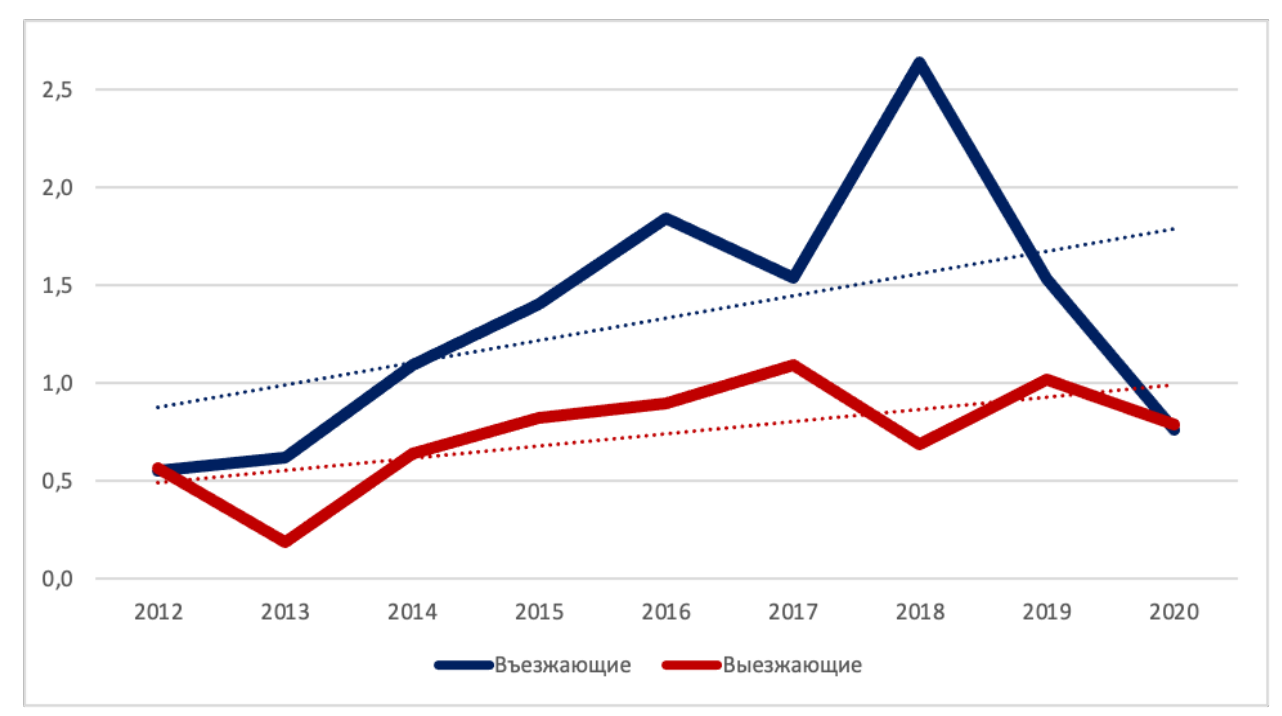

Диаграмма 2. Межрегиональная трудовая миграция в Республике Тыва, 2012-2020 г2., тыс. чел. ${ }^{2}$

Diagram 2. Interregional labor migration in the Republic of Tuva, 2012-2020, thousand people.

\footnotetext{
${ }^{1}$ Итоги выборочного обследования рабочей силы [Электронный ресурс] // Федеральная служба государственной статистики. URL: https://rosstat.gov.ru/compendium/document/13265 (дата обращения: 05.09.2021).

${ }^{2}$ Составлено автором по данным ОНПЗ и ОРС за 2012-2020 гг.
} 
Несмотря на определенные погрешности выборки, методологические изменения (к примеру, до 2017 г. опрашивалось население в возрасте 15-72 года, далее - все возраста, от 15 лет и старше), флуктуации в экономической ситуации, а также введение антиковидных мер, которые могли сильно повлиять на оценку величины межрегиональной трудовой миграции в 2020 г., очевидно, что темпы динамики числа въезжающих на работу в республику, и выезжающих, явно возрастают.

При этом число въезжающих в Туву на работу заметно превышало число выезжающих, за исключением года начала данных наблюдений (информация о межрегиональной трудовой миграции имеется с 2012 г.) и последнего на данный момент, 2020 г., который трудно считать показательным вследствие нетипичной эпидемиологической и экономической ситуации. При сравнении с другими регионами Сибирского федерального округа (таблицы 4 и 5) заметно, что показатели въезжающих внутрироссийских трудовых мигрантов и особенно выезжающих в Туву, заметно ниже, чем в других регионах, даже с сопоставимой численностью населения (Республикой Алтай, Хакасии). Тем не менее, нарастающие тренды свидетельствуют об усилении экономических связей с другими регионами страны.

Таблица 4. Число въезжающих на работу по регионам СФО, тыс. чел. ${ }^{1}$

Table 4. The number of people entering for work by the regions of the Siberian Federal District, thousand people.

\begin{tabular}{|l|c|c|c|c|c|c|c|c|c|}
\hline \multicolumn{1}{|c|}{ Территория } & 2012 & 2013 & 2014 & 2015 & 2016 & 2017 & 2018 & 2019 & 2020 \\
\hline СФО & 55,0 & 57,3 & 68,1 & 70,6 & 81,8 & 75,5 & 85,4 & 86,3 & 86,5 \\
\hline Республика Алтай & 0,1 & 0,9 & 0,4 & 1,2 & 1,3 & 0,8 & 3,3 & 1,7 & 0,8 \\
\hline Республика Тыва & 0,5 & 0,6 & 1,1 & 1,4 & 1,8 & 1,5 & 2,6 & 1,5 & 0,8 \\
\hline Республика Хакасия & 2,3 & 3,6 & 4,1 & 2,8 & 5,0 & 4,8 & 5,4 & 4,3 & 2,6 \\
\hline Алтайский край & 1,3 & 1,5 & 1,3 & 1,5 & 1,1 & 1,3 & 2,2 & 2,4 & 2,7 \\
\hline Красноярский край & 19,4 & 19,6 & 22,3 & 19,5 & 24,4 & 22,3 & 27,8 & 28,9 & 35,0 \\
\hline Иркутская область & 8,0 & 6,9 & 8,8 & 11,1 & 11,9 & 12,4 & 15,7 & 16,9 & 16,7 \\
\hline Кемеровская область & 3,7 & 2,2 & 2,5 & 3,8 & 3,5 & 6,4 & 3,0 & 8,3 & 4,4 \\
\hline Новосибирская область & 7,7 & 5,5 & 11,9 & 10,8 & 10,8 & 9,0 & 10,8 & 10,1 & 10,5 \\
\hline Омская область & 1,0 & 1,7 & 1,9 & 3,3 & 3,3 & 2,0 & 2,9 & 2,5 & 3,3 \\
\hline Томская область & 6,4 & 9,9 & 8,7 & 9,6 & 12,5 & 9,1 & 11,7 & 9,6 & 9,6 \\
\hline
\end{tabular}

Таблища 5. Число выезжающих на работу по регионам СФО, тыс. чел. ${ }^{2}$

Table 5. The number of people leaving for work by the regions of the Siberian Federal District, thousand people.

\begin{tabular}{|l|c|c|c|c|c|c|c|c|c|}
\hline \multicolumn{1}{r|}{ Территория } & 2012 & 2013 & 2014 & 2015 & 2016 & 2017 & 2018 & 2019 & 2020 \\
\hline СФО & 125,0 & 133,2 & 141,5 & 149,0 & 173,9 & 180,9 & 178,3 & 183,3 & 173,4 \\
\hline Республика Алтай & 0,3 & 0,5 & 0,5 & 0,8 & 1,2 & 1,6 & 2,2 & 2,7 & 2,4 \\
\hline Республика Тыва & 0,6 & 0,2 & 0,6 & 0,8 & 0,9 & 1,1 & 0,7 & 1,0 & 0,8 \\
\hline Республика Хакасия & 5,6 & 7,2 & 10,6 & 8,0 & 10,6 & 10,0 & 13,6 & 11,2 & 10,2 \\
\hline Алтайский край & 9,9 & 7,6 & 10,2 & 15,1 & 23,3 & 28,9 & 28,5 & 27,8 & 24,9 \\
\hline Красноярский край & 3,6 & 8,5 & 8,8 & 9,6 & 12,3 & 10,7 & 15,2 & 14,3 & 16,1 \\
\hline Иркутская область & 9,3 & 9,0 & 11,1 & 10,8 & 12,8 & 15,6 & 11,4 & 13,0 & 13,6 \\
\hline Кемеровская область & 7,8 & 6,6 & 12,3 & 10,9 & 14,8 & 10,6 & 20,0 & 15,9 & 14,9 \\
\hline Новосибирская область & 14,2 & 12,5 & 11,3 & 16,0 & 15,3 & 18,9 & 17,2 & 20,4 & 19,5 \\
\hline Омская область & 52,8 & 63,8 & 55,8 & 54,7 & 61,1 & 63,4 & 63,3 & 67,7 & 60,7 \\
\hline Томская область & 6,5 & 5,4 & 9,7 & 6,0 & 6,4 & 4,7 & 6,2 & 9,3 & 10,3 \\
\hline
\end{tabular}

${ }^{2}$ Составлено автором по данным ОНПЗ и ОРС за 2012-2020 гг. 
К сожалению, ОРС не может дать ответа на некоторые весьма важные вопросы о характере межрегиональной трудовой миграции Тувы, например, в какие регионы России она направлена из республики и, напротив, кто является «поставщиком» трудовых ресурсов для неё, а также направления миграции по категориям поселений (из села в село, из села в город, из города в город или, напротив, из города в село). Из-за того, что основные российские центры притяжения внутренних трудовых мигрантов (столичные регионы, Краснодарский край) географически расположены весьма отдаленно, по-видимому, потоки трудовых мигрантов из Тувы в большей степени направлены на газонефтедобывающие автономии Западной Сибири, а также Якутию и другие регионы Дальнего Востока и Крайнего Севера с неблагоприятными природными условиями, практикующие вахтовый метод работы с предоставлением жилья и с более высокими заработками, чем в Туве. Более подробные данные о внутренней трудовой миграции, включая информацию о территориях въезда и выезда, можно получить при помощи специализированных социологических обследований качественными и количественными методами, но также большие надежды связаны с предстоящей переписью населения - в программе ВПН-2021 значительно расширен блок вопросов как о миграции в целом, так и о внутренней трудовой мобильности постоянных жителей страны.

\section{Заключение}

C середины XX в. по настоящее время динамику численности населения Тувы определяют соотношение между собой естественного прироста (наблюдаемого как в городской, так и сельской местности) и миграционной убыли (всего населения и сельской ее части). Весьма высокий неттокоэффициент воспроизводства населения в Туве, заметно превышающий единицу, потенциально мог бы приводить к существенному росту численности населения, но этого в последние десятилетия не происходит из-за значительного превышения числа выбывших над прибывшими.

За последние полвека, согласно уравнению демографического баланса, суммарный миграционный отток населения превысил 100 тыс. чел, существенная часть которой пришлось на сельскую местность. Стоит отметить, что расчеты демографического баланса усложняются погрешностями текущего учета населения (особенно миграционного движения, в т. ч. вызванные сменой методики учета), качеством проведения переписей населения и накоплением ошибки закрытия баланса для межпереписных интервалов, а также административно-территориальными преобразованиями.

Сельская местность Тувы является важным «поставщиком» населения для городов самой республики, а также, вероятно, других регионов, с которыми установились наиболее тесные миграционные связи. Даже несмотря на высокую миграционную убыль, во всем населении республики, как и в городской его части, все еще наблюдается общий прирост населения из-за сохраняющегося заметного превышения рождаемости над смертностью. Замедление роста численности сельского населения в постсоветское время вызвало замедление роста общей численности населения республики.

Низкий уровень урбанизации является дополнительным фактором, который будет способствовать сохранению миграционного оттока из сельской местности в длительной перспективе. Стоит отметить, что исходя из опыта других российских регионов, миграционный отток вполне может происходить и при отрицательном уровне естественного прироста.

Среди важнейших особенностей демографической ситуации в республике - тот факт, что даже в городском, а не только в сельском населении до сих пор можно наблюдать высокую рождаемость. Это приводит к удивительному для современной России режиму воспроизводства, сочетающему естественный прирост с миграционной убылью.

В последние годы наблюдается усиление миграционных связей с Москвой, Санкт-Петербургом и их областями, хотя большая часть перемещений по-прежнему совершаются в соседние регионы. Вероятно, на соседние регионы, а также на Крайний Север и Дальний Восток направлены потоки и временной трудовой миграции из республики. При этом стоит отметить, что сам регион является небольшим по численности населения даже по меркам Сибирского федерального округа, и, несмотря на довольно высокий миграционный потенциал, не может оказывать заметного вклада в формирование населения других регионов России. 


\section{СПИСОК ЛИТЕРАТУРЫ}

Анайбан, З. В., Губогло, М. Н., Козлов, М. С. (1999) Формирование этнополитической ситуации. Т. 1. Очерки по истории постсоветской Тувы. М. : ЦИМО РАН. 412 с.

Анайбан, 3. В. (2011) Характеристика этнодемографических процессов Тувы в советский период // Новые исследования Тувы. № 2-3. С. 130-150.

Анайбан, 3. В. (2020) Современная миграционная ситуация в Республике Тыва // Sciences of Europe. № 49-4 (49). C. 62-66.

Андреев, Е. М. (2012) О точности результатов российских переписей населения и степени доверия к разным источникам информации // Вопросы статистики. № 11. С. 21-35.

Балакина, Г. Ф., Анайбан, 3. В. (2016) Особенности этнорегиональной миграции в Туве // Социологические исследования. № 10. С. 85-92.

Биче-оол, Т. Н., Допчут, А. А. (2015) Изменение административно-территориального деления Республики Тыва // Вестник Забайкальского государственного университета. № 9 (124). С. 4-9.

Денисенко, М. Б., Степанова, А. В. (2012) География происхождения жителей Москвы. Расселение населения // Демографические исследования. № 19. С. 133-168.

Кан, В. С. (2014) Миграция как фактор межэтнической напряженности в Республике Тыва // Конфликтология. № S. C. 218-220.

Карачурина, Л. Б., Мкртчян, Н. В. (2013) Внутрироссийская миграция // Население России 2010-2011. Восемнадцатый-девятнадцатый ежегодный демографический доклад / отв. ред.: А. Г. Вишневский. М. : Издательский дом НИУ ВШЭ. 530 с. С. 444-473. DOI: http://doi.org/10.17323/978-5-7598-1772-7

Карачурина, Л. Б., Мкртчян, Н. В. (2016) Население центров и глубинки в России, Украине и Белоруссии [Электронный ресурс] // Демоскоп Weekly. № 699-700. C. 1-27. URL: http://demoscope.ru/weekly/2016/0699/tema01.php (дата обращения: 05.10.2021).

Ламажаа, Ч. К. (2014) Засаянские тувинцы: образ жизни, ценности, идеалы // Новые исследования Тувы. № 3. C. $152-165$.

Мкртчян, Н. В. (2011) Динамика населения регионов России и роль миграции: критическая оценка на основе переписей 2002 и 2010 гг. // Известия Российской академии наук. Серия географическая. № 5. C. 28-41. DOI: http:// doi.org/10.1134/S2079970511030087

Мкртчян, Н. В. (2020) Проблемы в статистике внутрироссийской миграции, порожденные изменением методики учета в 2011 г.// Демографическое обозрение. № 7(1).C. 83-99.DOI: https://doi.org/10.17323/demreview.v7i1.10821

Мкртчян Н. В., Карачурина Л. Б. (2014) Внутрироссийские миграции // Население России 2012: двадцатый ежегодный демографический доклад / отв. ред. А. Г. Вишневский. М. : Издательский дом НИУ ВШЭ. 412 с. С. $309-342$.

Пьянкова, А. И. (2014) Методические проблемы сопоставимости данных переписей населения 2002 и 2010 годов (на примере Московской области) // Региональные исследования. № 1. С. 109-121.

Самба, А. Д. (2020) Основные изменения в социально-трудовом пространстве Республики Тыва // Экономика и управление: научно-практический журнал. № 1. С. 47-50. DOI: https://www.doi.org/10.34773/EU.2020.1.12

Харунова, М. М.-Б., Харунов, Р. Ш. (2021) Особенности формирования городского расселения в Туве в советский период // Новые исследования Тувы. № 3. С. 137-147. DOI: https://www.doi.org/10.25178/nit.2021.3.11

Чудиновских, О. С. (2010) Современное состояние статистики миграции в России: новые возможности и нерешенные проблемы // Вопросы статистики. № 6. С. 8-16.

Abylkalikov, S. I., Sazin, V. S. (2019) Migration in the Kaliningrad region reflected in the 1989-2015 censuses and microcensuses // Baltic Region. Vol. 11. № 2. C. 32-50. DOI: https://www.doi.org/10.5922/2079-8555-2019-2-3

Дата поступления: 12.10.2021 2.

\section{REFERENCES}

Anaiban, Z. V., Guboglo, M. N. and Kozlov M. S. (1999) Formirovanie etnopoliticheskoi situatsii [Shaping the ethnopolitical situation]. Moscow, Center for the Study of Interethnic Relations RAS. Vol. 1: Ocherki istorii postsovetskoi Tuvy [Essays on the history of post-Soviet Tuva]. 420 p. (In Russ.). 
Anaiban, Z. V. (2011) Kharakteristika etnodemograficheskikh protsessov Tuvy v sovetskii period [Characteristics of ethnodemographic processes in Tuva during the Soviet period]. New Research of Tuva, no. 2-3, pp. 130-150. (In Russ.).

Anaiban, Z. V. (2020) Sovremennaia migratsionnaia situatsiia v Respublike Tyva [Contemporary migration situation in the Republic of Tuva]. Sciences of Europe, no. 49-4 (49), pp. 62-66. (In Russ.).

Andreev, E. M. (2012) O tochnosti rezul'tatov rossiiskikh perepisei naseleniia i stepeni doveriia k raznym istochnikam informatsii [On accuracy of Russia population censuses results and level of confidence in different sources of information]. Voprosy statistiki, no. 11, pp. 21-35. (In Russ.).

Balakina, G. F. and Anaiban, Z. V. (2016) Osobennosti etnoregional'noi migratsii v Tuve [Specific features of ethnoregional migration in Tuva]. Sotsiologicheskie issledovaniia, no. 10, pp. 85-92. (In Russ.).

Biche-ool, T. N. and Dopchut, A. A. (2015) Izmenenie administrativno-territorial'nogo deleniia Respubliki Tyva [Change in the administrative territorial division of the Republic of Tuva]. Vestnik Zabaikal'skogo gosudarstvennogo universiteta, no. 9 (124), pp. 4-9. (In Russ.).

Denisenko, M. B. and Stepanova, A. V. (2012) Geografiia proiskhozhdeniia zhitelei Moskvy. Rasselenie naseleniia [Geography of the origin of the inhabitants of Moscow. Displacement of population]. Demograficheskie issledovaniia, no. 19, pp. 133-168. (In Russ.).

Kan, V. S. (2014) Migratsiia kak faktor mezhetnicheskoi napriazhennosti v Respublike Tyva [Migration as the factor of interethnic tension in the Republic of Tuva]. Konfliktologiia, no. S, pp. 218-220. (In Russ.).

Karachurina, L. B. and Mkrtchyan, N. V. (2013) Vnutrirossiiskaia migratsiia [Internal Russian migration]. In: Naselenie Rossii 2010-2011. Vosemnadtsatyi-deviatnadtsatyi ezhegodnyi demograficheskii doklad [The population of Russia in 20102011. Eighteenth and nineteenth annual demographic report] / ed. by A. G. Vishnevskii. Moscow, HSE Publishing House. 530 p. Pp. 444-473. (In Russ.). DOI: http://doi.org/10.17323/978-5-7598-1772-7

Karachurina, L. B. and Mkrtchyan, N. V. (2016) Naselenie tsentrov i glubinki v Rossii, Ukraine i Belorussii [The population of the centers and the hinterland in Russia, Ukraine and Belarus]. Demoskop Weekly, no. 699-700, pp. 1-27. [online] Available at: http://demoscope.ru/weekly/2016/0699/tema01.php (access date: 05.10.2021). (In Russ.).

Lamazhaa, Ch. K. (2014) Zasaianskie tuvintsy: obraz zhizni, tsennosti, idealy [Tuvans beyond the Sayan Mountains: Way of living, values and ideals]. New Research of Tuva, no. 3, pp. 152-165. (In Russ.).

Mkrtchyan, N. V. (2011) Dinamika naseleniia regionov Rossii i rol' migratsii: kriticheskaia otsenka na osnove perepisei 2002 i 2010 gg. [Population dynamics of Russia's regions and the role of migration: Critical assessment based on the 2002 and 2010 censuses]. Izvestiia Rossiiskoi akademii nauk. Seriia geograficheskaia, no. 5, pp. 28-41. (In Russ.).

Mkrtchyan, N. V. (2020) Problemy v statistike vnutrirossiiskoi migratsii, porozhdennye izmeneniem metodiki ucheta v 2011 g. [Problems in the statistics of internal Russian migration caused by changes in accounting methods in 2011]. Demographic Review, no. 7 (1), pp. 83-99. (In Russ.). DOI: https://doi.org/10.17323/demreview.v7i1.10821

Mkrtchyan, N. V. and Karachurina, L. B. (2014) Vnutrirossiiskie migratsii [Internal Russian migrations]. In: Naselenie Rossii 2012: dvadtsatyi ezhegodnyi demograficheskii doklad [Population of Russia 2012: The twentieth annual demographic report] / ed. by A. G. Vishnevskii. Moscow, HSE Publishing House. 412 p. Pp. 309-342. (In Russ.).

Pyankova, A. I. (2014) Metodicheskie problemy sopostavimosti dannykh perepisei naseleniia 2002 i 2010 godov (na primere Moskovskoi oblasti) [Methodological problems of comparability of data from the 2002 and 2010 population censuses (The case of Moscow region)]. Regional'nye issledovaniia, no. 1, pp. 109-121. (In Russ.).

Samba, A. D. (2020) Osnovnye izmeneniia v sotsial'no-trudovom prostranstve Respubliki Tyva [Major changes in the socio-labor space of the Republic of Tuva]. Ekonomika i upravlenie: nauchno-prakticheskii zhurnal, no. 1, pp. 47-50. (In Russ.). DOI: https://doi.org/10.34773/EU.2020.1.12

Kharunova, M. M.-B. and Kharunov, R. Sh. (2021) Osobennosti formirovaniia gorodskogo rasseleniia v Tuve v sovetskii period [Features of urban settlement in Tuva in the Soviet period]. New Research of Tuva, no. 3, pp. 137-147. (In Russ.). DOI: https://doi.org/10.25178/nit.2021.3.11

Chudinovskikh, O. S. (2010) Sovremennoe sostoianie statistiki migratsii v Rossii: novye vozmozhnosti i nereshennye problemy [The current state of migration statistics in Russia: New opportunities and unresolved issues]. Voprosy statistiki, no. 6, pp. 8-16. (In Russ.).

Abylkalikov, S. I. and Sazin, V. S. (2019) Migration in the Kaliningrad region reflected in the 1989-2015 censuses and microcensuses. Baltic Region, vol. 11, no. 2, pp. 32-50. DOI: https://doi.org/10.5922/2079-8555-2019-2-3

Submission date: 12.10.2021. 